\title{
An Analysis of Illocutionary Act in Incredible 2 Movie
}

\author{
Partohap Saut Raja Sihombing ${ }^{1}$, Dumaris E. Silalahi ${ }^{2}$, Debby Intragedy Saragih ${ }^{3}$, \\ Herman $^{4}$ \\ ${ }^{1,2,3,4}$ English Education Department, Universitas HKBP Nommensen, Medan, Indonesia \\ partohap.sihombing@uhn.ac.id,dumaris.silalahi@uhn.ac.id,debbysaragih11@gmail.com, \\ herman@uhn.ac.id
}

\begin{abstract}
The objective of this research is to analyze the types of illocutionary act in the Incredible 2 movie and to interpret the dominant types of illocutionary act. Searle's theory are used by the researchers to answer the formulated research questions. This research is a qualitative research applying content or document analysis. The subject of this research is a movie entitled Incredible 2 movie The data were some scene including the illocutionary act in Incredible 2 movie. To collecting the data, the researchers downloading the movie from google, watching the film "Incredible 2" for several time, then searching for the script of the movie in the internet, watching the movie while reading the script, finding some sentences that are considered to have illocutionary act needed for the analysis and found the dominant types of illocutionary act, After collected the data, the researchers analyze the data based on some steps, classifying the illocutionary act, finding the dominant types of the illocutionary act, The findings of the research are as follows: in Incredible Movie, Searle's theory there are 5 types of illocutionary act are found: From those types, in movie Incredible found the types of illocutionary act as follows : directives consist of 8 data (32\%), assertive consist of 7 data (28\%), expressive consist of 7 data (28\%), commisive consist of 2 data $(8 \%)$ and declaration sonsist of 1 data(4\%).
\end{abstract}

Keywords

pragmatic, speech act; illocutionary, movie

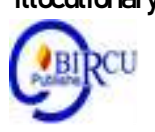

\section{Introduction}

Language is a basic tool in society. It is used to make communication. According to Pardede et al (2019:1), language is communication tool between members of society. Then, according to Herman (2017:72), language is used as means of communication, by language we can talk to our friends, express our ideas, and feelings (Sinaga, Herman and Siahaan, 2020; Pasaribu, Hutahaean, and Herman, 2020). From the definition, it can be said that language is used by people to express their thoughts, feelings, ideas and the fact that every day we used it to communicate in daily activities.

There are many kinds of languages in the world. There is one language that becomes International language and is used by people around the world, that is English. English is the most widely learned language all over the world because of its status as an international language. As an international language, therefore, English has a special function for being a lingua franca among people with different languages in the world. In other words, English is a language which is able to link people with different nations and languages to communicate in international scope. English is a global language that is used as a communication device between nations of different language. Mappiasse and Johari 
(2014:113) state that English language is one of the most spoken languages in the world of today (Herman, 2016; Sinaga, Herman, and Pasaribu, 2020). English language becomes the most essential language in the world because almost all the people from many different countries around the world use it to communicate and to interact with the other people. English plays an important role in process of communication among them and also English can accelerate science and technological development of a nation.

As one of branches in linguistic, pragmatic is the study of how linguistic greatly influences human's speech. People often used indirect speech in conversation which the meaning is different from sentence they speak. Therefore, the researchers take speech act and context as the clarifying of her research. Communication is not just symbols, words or sentences, but it will be more appropriate if it called product or result of the symbol, word or phrase in the form of speech acts behavior. According to Ridwan (2018) the function of official language is usually dealing with certain business in a certain territory such as nation ${ }^{\text {ee }}$ court, parliament, and administration and it is not widely spoken in the society. However, it is possible that one language serves both functions.

Pragmatics is study about speaker meaning. In other word, in pragmatics, we study about the meaning of the context between the speaker and hearer. The context is an important thing in pragmatic study because context is the background knowledge assumed to be shared by the speaker and hearer and which contributes to the hearer's interpretation of what the speaker means by giving an utterance. Actually, pragmatics have been studied many types, such as deixis and distance, reference and inference, presupposition and entailment, politeness and interaction, speech act and event, and others. But in here, the researchers just focus on speech act. According to Mono (2018) Pragmatics as one of linguistic studies, specially studies the correlation between language and speech context. Supriyadi (2020) stated that interpret speech utterances, the speaker"s uses a means-end analysis strategy, while the speech partner's task uses heuristic analysis strategies. The heuristic strategy seeks to identify the pragmatic force of a speech by formulating hypotheses and then testing it based on available data.

Speech act is act when the speaker says utterances. According to Yule as cited in Mufiah and Rahman (2018:126), speech acts consists of three related acts, the first is a locutionary act, which is the basic act of utterance, or producing a meaningful linguistic expression. Mostly we don't just produce well-formed utterances with no purpose. We form an utterance with some kind of function in mind. The second dimension is Illocutionary act. That is performed via the communicative force of an utterance. We do not create an utterance with a function without intending it to have an effect. This is the third dimension, the perlocutionary act. Illocutionary acts is the function of the word, the specific purpose that the speakers have in mind.

The most important study from three kinds of speech act is illocutionary acts, it becomes the basic of analysis in pragmatics comprehension. Each type of illocutionary acts above has a different context and meaning. First representative, that the speaker believes something being the case or not. Second is directive when the speaker requesting to the listener, listener perform an action. Third, commisive, asks the speaker to do something in the future. The fourth is expressive, it shows an expression how the speaker feels about the situation. The last is declarative, it changes world by the utterance which is produced.

The used of illocutionary can be expressed in literature. A literature can be found within songs, poems, movies and others. Movie is one media that reflects the social life of human. There are many types of movies nowadays including horror movies, action movies, dramas, and animated movies. Animated movie is a movie which shows animated character and funny stories. This movie can be a good object to analyze the case of 
illocutionary acts. For recent years, movie considered being an important art form, as a root of en vogue entertainment but now movie also became a source of education for citizens learned and got education from films was possible because of many messages that implied and founded there. Moreover, there were also insert values such as moral values, educational values and other values.

Watching movie more easily to understand when the movie contains of subtitles. The most important thing is mostly occured within the movies is the conversation among the characters. When the characters speak each other it will be illocutionary act. In communicating people use utterances with implied meanings. The meaning can be categorized from the context. While communicate with each other it is important to understand the context to know the speaker's intention. As Leech (1983:13) explains context is any background knowledge assumed to be shared by speaker and hearer which contributes to hearer interpretation of what speaker means by given an utterance, it means that to be able to understand what the speaker says so the hearer must have the same background knowledge with the speaker which is the context. It is difficult for the hearer to interpreting the meaning from the speaker, because if there is no context the communication is useless or fail, because it can make the hearer confused to know the speaker's intention. Furthermore, Hymes as cited in Wardaugh (2006) the eight aspects in communication, namely setting and scene, participants, end, act sequence, key, instrumentalities, norms and genre or speaking context. These elements are very important in daily communication, because the different aspects can influence the meaning in communication with others.

Speech acts can be found in conversation of movie. The conversation in the movie can be an excellent example of speech acts because it represents the complicated case of speech acts in order to find out what the main character does by saying something. The one of important that mostly occurred in the movie is the dialogue among the characters. Here the researchers wants to analyze illocutionary act that is used in the movie. The researchers interested to analyze about illocutionary act because some problem, sometimes in everyday life there is still misunderstanding in communication. This misunderstanding occurs between the speaker and listeners. To minimize misunderstanding, a study of speech act is needed where the speech act is a linguistic study that studied about the intent of utterances. When we understand the intent of utterance, misunderstandings in communication will not occur. This encourages the researchers to conduct the research related illocutionary speech act.

This study was conducted to find out types of illocutionary acts on movie. The problems that make the research was interested to be discussed. This intended meaning existed almost in every speaker's utterances and most of the speakers did not realize that they performed the illocutionary act in their utterances. The aims of the research were to describe the types of illocutionary act in the "Incredible 2" movie and also to describe the function of illocutionary act.

An example of illocutionary act that found in Incredible 2 movie minutes to 00:18:42

Evelyn : As soon as he knew there was trouble

Deavor : I disagree strongly

Evelyn : But we are not going into it right now

This conversation occurs in the office. Deavor invite all superhero to talk about that superhero not should be formal. So, Deavor said "I disagree strongly"

The utterances contain implied meaning, which may be interpreted as Deavor does not agree with the rule of the government. In this case, Deavor says "I disagree strongly" to 
express his rejection. Deavor utterance is categorize as assertive. Another researcher that use an illocutionary act in her research is Ciptaningrum (2017) entitled "The Analysis of illocutionary Acts by The Main Character in The Film Entitled Cinderella an Its Application in teaching speaking at the Tenth Grade of Senior High School". The result of the research shows that the form of comissive that found in the Vow movie, it can be said that there is significant different to this research. The different is the previous study just focus to analyze commisive in movie.

Besides, this study also analyzes the contexts occurring in some conversations. The data used in this study were taken from the movie Incredible movie. This study tried to find out types of illocutionary act used in movie. And from that, this study also analyzes the contexts. Hopefully, this study can help us to learn more and understand about the types of illocutionary act in the movie Incredible. So, from the explanation above, researchers can make the title "An Analysis of Illocutionary Act in Incredible 2 Movie"

\section{Research Methods}

\subsection{Research Design}

A research method used was qualitative. According to Ary in Herman et al (2019:44), qualitative researchers seek to understand a phenomenon by focusing on the total picture rather than breaking it down into variables. The goal is a holistic picture and depth of understanding rather than a numeric analysis of data. Qualitative research to analyze the types of illocutionary acts that are found in Incredible 2 movie.

Purba and Herman (2020:25) stated that qualitative approach is used to describe the data. One of the characteristics of the qualitative method is to see the process we have to deal with according to the setting; the place where the research will be carried out. There were seven types of qualitative research. There were case studies, content or document analysis, ethnographic studies, grounded theory studies, historical studies, narrative research, phenomenological research (Ary et al. 2010:452-453). The researchers used content or document analysis. According to Ary et al. (2010:457), content or document analysis is a research method applied to written or visual materials for the purpose of identifying specified characteristics of the materials. The materials analyzed can be text book, newspaper, web pages, speeches, television programs, advertisements, musical compositions, or any of a host of other types of documents. The researchers chose movie as an object of this research. The movie has the script that can be analyze.

\subsection{Data and Data Source}

The aim of the research was to get data. According to Arikunto (2010:129) say that the data are information or facts used in discussing or deciding the answer of research question. The source of data in the study was the subjects from which the data can be collected for the purpose of research. The researchers got the data source from the movie English subtitle "Incredible 2". By this movie, the researchers checked the utterance that the characters said in movie. And then found out the Illocutionary act especially five types of Illocutionary act in the movie script that had the total duration on 01.59.13. This movie was release 2018. The researchers chose this movie because this movie an animation movie. This movie was a highest rating and this film we got moral values and educational values. This film is very interesting to watch, because this film tells the story follows the Parr family as they try to restore the public's trust in superheroes while balancing their family life, only to combat a new foe who seeks to turn the populace against all superheroes. 


\subsection{Research Instrument}

Instrument was tools that are required to get information. Gay and Airasian (2000: 145) stated that instrument is a tool that is used in collecting data. As according to Sugiyono (2008:222) stated that in qualitative research, the researchers is the key instrument. There are some media that researchers using in this research;

a) Laptop, the researchers using laptop in this research to watch the movie. Movie as an object in this research

b) Script movie, the researchers using script as the research documents. Document helps the researchers to analyze the movie.

c) Notes, the research using notes to write the importance of point from the movie.

\subsection{Data Collection}

The researchers used qualitative approach which the form of data is utterances. According to Marshall (2006) "Qualitative approach typically relies on four methods for gathering information:

1) Participating in the setting,

2) Observing directly,

3) Interviewing in depth, and

4) Analyzing documents and material culture.

The researchers used documentation in collecting the data. According to Arikunto (2010:274) a documentation method is find the data that related by using book, transcripts, newspaper, magazines, notes of meeting, ancient inscription, and agenda.

There are some steps to collect data in this research:

1. Downloading the movie from google: http://149.56.24.226/incredible-2019/

2. Watching the film "Incredible 2" for several time

3. Searching for the script of the film in the internet.

4. Watching the movie while reading the script

5. The researchers determined the art of dialogue that presened types of illocutionary act

6. The researchers collecting utterance from the script on the movie

7. Identifying the data based on the type of illocutionary (Assertives, Directives, Commisive, Expressives, Declarations)

\subsection{Technique of Data Analysis}

In this research, the researchers used the content analysis in which the writer tries to analyze data and to identify every utterance using illocutionary acts. Then, the researchers described the data which will answer the two research questions of data analysis above. According to Sugiyono (2007:207) data analysis is an activity done after the data of sources has been gathered. Data analysis is the process of systematically applying to describe and illustrate the data.

In conducting this research, the researchers provided some ways to analyze the data as following:

1. Watching and understanding movie "Incredible 2"

2. Reading the script of movie "Incredible 2"

3. Finding the data in the form of conversational fragments of the main character containing illocutionary acts from the script of movie "Incredible".

4. The data were analyzed, grouped into their own types and transfer into data sheets,

5. The researchers described and interpreted the data in order to answer the formulation of the problems, and during the process of analysis, the researchers applied the worthiness of the data and analyzed the data to gain the results of the research. 


\subsection{Triangulation}

In this research, the researchers used triangulation technique. Cohen (2000:112) stated "Triangulation may be defined as the use of two or more methods of ata collection in the study of some aspect of human behavior". Thus, triangulation technique means the researchers uses two or more techniques in collecting data to get validity. The purpose of triangulation is to increase the credibility and validity of the findings. Further, Denzin in Patton (2009) stated that there are four techniques in triangulation. Those are: (1) source triangulation, (2) investigator triangulation, (3) methodological triangulation, (4) theoretical triangulation

\section{Source triangulation}

In source triangulation, the researchers uses many sources or participants to get the accuracy of data

2. Investigator triangulation

Investor triangulation means technique that uses more than one researchers in collecting and analyzing data. From some researchers' view in interpreting information and collecting the data, the validity of data can be increased

3. Methodological triangulation

Methodological triangulation refers to researchers uses more than one method in the research. Cohen (2000:113) explained "Methodological triangulation is using the same method on different occasions or different method on the same object of the study". Thus, methodological triangulation is making different method to et validity of data.

4. Theoretical triangulation

Theoretical triangulation means the researchers compares the data finding with perspective theory that is relevant. Here, the researchers is demanded to have expert judgment to compare the finding of the research with the certain theory.

From those types of triangulation, the researchers used source triangulation of data. Besides, the researchers collected the data by collected document. The source of the data refers to the types of illocutionary act that used by character based on Searle theory. In checking the data, the researchers analyze the data by expert theories.

\section{Results and Discussion}

There are two findings of Illocutionary Act that found in Incredible movie:

\subsection{Types of Illocutionary Act}

Based on the data analysis, the researchers found that there are 5 types of illocutionary act that found in Incredible 2 movie, there are directives consist of 8 data (32\%), assertive consist of 7 data (28\%), expressive consist of 7 data $(28 \%)$, commisive consist of 2 data $(8 \%)$ and declaration consist of 1 data(4\%). The detail result of the types can be seen in the following table:

Table 1. Type of Illocutionary Act in Incredible 2 Movie

\begin{tabular}{|l|l|c|c|c|c|c|}
\hline & \multicolumn{1}{|c|}{ Utterances } & \multicolumn{4}{|c|}{ Types of Illocutionary Act } \\
\cline { 3 - 7 } No. & \multicolumn{1}{|c|}{\begin{tabular}{|l} 
B \\
Behold! The Underminer! I am always beneath \\
you, but nothing is beneath me”
\end{tabular}} & $\sqrt{ }$ & & & & \\
\hline 2. & You two, stay here & $\sqrt{ }$ & & & & \\
\hline 3. & One of you patrol the perimeter, keep the crowds & & $\sqrt{ }$ & & & \\
\hline
\end{tabular}




\begin{tabular}{|c|c|c|c|c|c|c|}
\hline \multirow[b]{2}{*}{ No. } & \multirow[b]{2}{*}{ Utterances } & \multicolumn{5}{|c|}{ Types of Illocutionary Act } \\
\hline & & A & $\mathbf{D}$ & $\mathbf{E}$ & $\mathbf{C}$ & $\mathbf{D L}$ \\
\hline & back and save. The other, watch after jack-jack" & & & & & \\
\hline 4. & But we're supposed to help, if there's trouble & & $\sqrt{ }$ & & & \\
\hline 5. & Honey, let's just at least hear what he has to say & & $\sqrt{ }$ & & & \\
\hline 6. & Good to see you. I'm your biggest fan" & $\sqrt{ }$ & & & & \\
\hline 7. & $\begin{array}{l}\text { So, if we wanna change people's perception about } \\
\text { superheroes... We need you to share your } \\
\text { perception to the world" }\end{array}$ & & $\sqrt{ }$ & & & \\
\hline 8. & Thanks! Designed 'em myself & & & $\sqrt{ }$ & & \\
\hline 9. & $\begin{array}{l}\text { One, do this right, get well paid, we're out of the } \\
\text { motel and things get better for all supers, } \\
\text { including our kids. Or two, I find a job in two } \\
\text { weeks or we're homeless }\end{array}$ & & $\sqrt{ }$ & & & \\
\hline 10. & Thanks for handling everything & & & $\sqrt{ }$ & & \\
\hline 11. & $\begin{array}{l}\text { Quick go! Protect the ambassador! Open the } \\
\text { door, do as she says }\end{array}$ & & $\sqrt{ }$ & & & \\
\hline 12. & $\begin{array}{l}\text { Im happy, im happy The numbers are up, im } \\
\text { happy the ambassador is pro superhero, and } i \\
\text { happy you are happy }\end{array}$ & $\sqrt{ }$ & & & & \\
\hline 13. & I just want to thank you, for being you & & & $\sqrt{ }$ & & \\
\hline 14. & You sound like my brother & $\sqrt{ }$ & & & & \\
\hline 15. & Thats my car & $\sqrt{ }$ & & & & \\
\hline 16. & $\begin{array}{l}\text { "I'm sure filling in for Helen is chalenging, and } \\
\text { you are very tired and the other Children need } \\
\text { you, and miss you, and you must go to them" }\end{array}$ & & $\sqrt{ }$ & & & \\
\hline 17. & $\begin{array}{l}\text { Hey, Im just used Technology to destroy people's } \\
\text { trust in it }\end{array}$ & $\sqrt{ }$ & & & & \\
\hline 18. & But father insisted, they all his superhero friends & & & $\sqrt{ }$ & & \\
\hline 19. & Hey, what about your turning the boat?" & & $\sqrt{ }$ & & & \\
\hline 20. & $\begin{array}{l}\text { Thankyou.. thankyou so much. Thankyou, } \\
\text { Ambassador, for early and very crucial support }\end{array}$ & & & $\sqrt{ }$ & & \\
\hline 21. & They'll join for the signung & & & & $\sqrt{ }$ & \\
\hline 22. & Hey, what about turning the boat? & & & $\sqrt{ }$ & & \\
\hline 23. & You lost him? I gave you one thing to do & & & $\sqrt{ }$ & & \\
\hline 24. & All supers, protect your ambassador & & & & & $\sqrt{ }$ \\
\hline 25. & I'll be back before the previews are over. & & & & $\sqrt{ }$ & \\
\hline
\end{tabular}




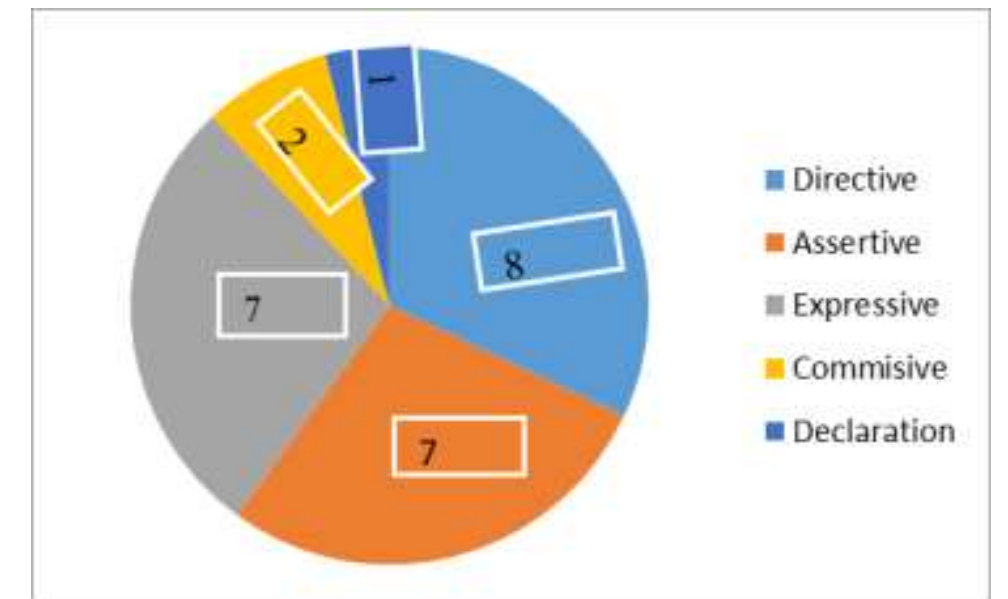

Figure 1. The types of illocutionary act found in Incredible 2

\subsection{Dominant Types of Illocutionary Act}

After classifying and analyzing the data in the types of illocutionary act by using Searle's theory, it can be seen from the result of percentage that directive is the most dominant than other types. In the second position is assertive and the last position is declaration. The detail result of the types of illocutionary act can be seen in the following table:

Table 2. Type of Illocutionary Acts in Incredible 2 Movie

\begin{tabular}{|l|l|c|c|}
\hline No. & Types of Idiomatic Expressions & Frequency & Percentages \\
\hline 1. & Directive & 8 & $32 \%$ \\
\hline 2. & Assertive & 7 & $28 \%$ \\
\hline 3. & Expressive & 7 & $28 \%$ \\
\hline 4. & Commisive & 2 & $8 \%$ \\
\hline 5. & Declaration & 1 & $4 \%$ \\
\hline \multicolumn{2}{|c|}{ Total } & $\mathbf{2 5}$ & $\mathbf{1 0 0 \%}$ \\
\hline
\end{tabular}

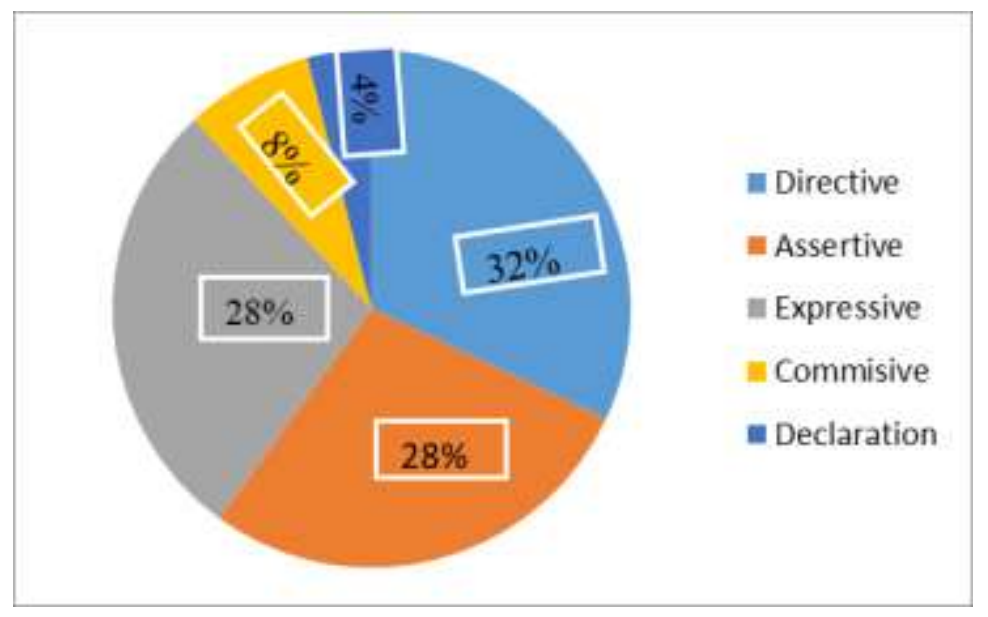

Figure 2. The dominant types of illocutionary act found in Incredible 2 


\subsection{Discussion}

After analyzed the data, the researchers discussed the whole data and answer the research questions. This research discussed about illocutionary act that found in Incredible 2 movie. Incredible 2 premied in Los Angels on June 5, 2018 from Disney Digital 3D. The researchers used Searle theory. There are 5 types of illocutionary act: assertive, directive, expressive, commisive and declaration. As the answer of the research problems that been formulated in Chapter 1, this research investigates the types of illocutionary act that occurs in Incredible 2 movie and dominant types of illocutionary act. The researchers analyzed the data based on some steps, firstly the researchers watched and understood movie "Incredible 2", reading the script of movie "Incredible 2", found the data in the form of conversational fragments of the character containing illocutionary acts from the script of movie "Incredible 2", the data were analyzed, grouped into their own types and transfer into data sheets, and the last described and interpreted the data in order to answer the formulation of the problems, and during the process of analysis, the researchers applied the worthiness of the data and analyzed the data to gain the results of the research.

In the first section, the researchers discussed the first research problems; what are the types of illocutionary act that found in Incredible 2 movie. The second, the researchers discussed the; what is the dominant types of illocutionary act in Incredible 2 movie. The explanation of this discussion based on the finding, the researchers found 25 data containing illocutionary act that occurs in Incredible 2 movie.

This research has similarities and differences with some other researchers like from research completed by Herman (2015) entitled "Illocutionary Acts Analysis of Chinese in Pematangsiantar. The differences between the previous study and this study is the previous study analyze the utterances of Chinese who live in Hos Cokroaminoto, Pematangsiantar but in this research the researchers analyzed the utterances in the Incredible 2 movie and then the similarities of this study with previous study is using Searle's theory to find out the types of illocutioary act. Austin (1975:3) stated that there are three types of speech acts, namely locutionary, illocutionary, and perlocutionary acts. But in this occasion, the writer focuses to illocutionary acts. Illocutionary act has five types, they are representatives, directives, commissives, expressive, and declarative (Searle in Leech, 1983:205). So the writer uses the types of illocutionary acts to analyze the utterances of Chinese who live in Hos Cokroaminoto, Pematangsiantar. Problem discussed in this research is what types of illocutionary acts are found on Chinese conversation in Pematangsiantar? To answer the problem, Descriptive qualitative method was adapted in this research. The writer uses sampling data in order to make the research become more efficient. Data were taken from the various contexts which has some conversations. Finally, the writer found that there are only four types of illocutionary acts occurred in the utterances of Chinese who live in Hos Cokroaminoto, Pematangsiantar. The types of illocutionary acts occurred in the utterances of Chinese who live in Hos Cokroaminoto, Pematangsiantar are Representative (typical of structure expressions of asking), Directive (typical of structure expressions of ordering and inviting), Expressive (typical of structure expressions of greeting and compliment), and Commissive (typical of structure expressions of threatening). 


\section{Conclusion}

From the study done by the researchers, it is known that in the movies especially Incredible 2 Movies there are phrase that contain of illocutionary. The conclusion of them as follows:

1. The first statement of the problem of this research is to analyze the types of illocutionary act in Incredible 2 movie. Here, the researchers found out 25 illocutionary act that are in movies. Based on Searle's theory, there are 5 types of illocutionary either it is assertive, directive and expressive, commisive and declaration. From those types, in movie Incredible found the types of illocutionary act as follows: directives consist of 8 data (32\%), assertive consist of 7 data (28\%), expressive consist of 7 data (28\%), commisive consist of 2 data (8\%) and declaration consist of 1 data (4\%).

2. For second question of this research is analysis the dominant types of the illocutionary act. Based on the result of analyzed types of illocutionary, the researchers found the dominant types of illocutionary that used in the Incredible 2 movie. The dominant types of illocutionary act is directives.

Based on the findings and discussions above, the researchers concluded that in Incredible 2 movie contained all types of illocutionary act based Searle's theory which are assertive, directive and expressive, commisive and declaration. After the researchers analyzing and presenting all of the data, the researchers concluded that there are three types of illocutionary act contained in Incredible 2 movie. In the research finding, the researchers found 25 data from script of Incredible 2 movie.

\section{References}

Akmala, Tatum Ariesya. (2011). The Use of Animated Film to Imrove students' Ability in Writing Narrative Text. Semarang: Tarbiyah Faculty Walisongo State Institute for Islamic Studies Semarang.

Aoudah. (2016). A Study of Social Values In The Legend Of Korra, p. 4 (On-Line), available on: http://fkipunram.rf.gd/uploads/E1D110031. pdf (February 27th 2018)

Arikunto, Suharsimi. (2010). Prosedur Penelitian Suatu Pendekatan Praktek. Jakarta: Rineka Cipta.

Ary, D.; Jacob, L.; Sorensen, C. (2010). Introduction to Research in Education. 8th. Edition. USA: WARDSWORTH Cengage Learning

Austin, J. L. (1962). How to do thing with words. Massachusetts: Yeshiva University, President and Fellow

Chojimah, Nurul. (2015). Utterances and Their Meanings (teaching material). Tulungagung: State Islamic Islamic Institute of Tulungagung

Cutting, Joan. (2002). Pragmatics and Discourse. London and New York: Routledge.

Denzin, N. K and Yvonna S. L. (2009). Handbook of Qualitative Research. Yogyakarta: Pustaka Belajar.

Herman. (2015). Illocutionary Acts Analysis of Chinese in Pematangsiantar. International Journal of Humanities and Social Science Invention, Volume 4 Issue 12, PP.41-48. Retrieved from http://www.ijhssi.org/papers/v4(12)/Version-2/E0401202041048.pdf

Herman. (2016). Students' Difficulties in Pronouncing the English Labiodental Sounds. Communication and Linguistics Studies. Vol. 2, No. 1, 2016, pp. 1-5. doi: 10.11648/j.cls.20160201.11. Retrieved from http://www.sciencepublishinggroup.com/journal/paperinfo?journalid=357\&doi=10.1 1648/j.cls.20160201.11 
Herman. (2017). Shift in Translation from English into Indonesia on Narrative Text. International Journal of European Studies. Vol. 1, No. 3, 2017, pp. 72-77. doi: 10.11648/j.ijes.20170103.12. Retrieved from http://www.sciencepublishinggroup.com/journal/paperinfo?journalid=520\&doi=10.1 1648/j.ijes.20170103.11

Herman and Silalahi, D. E. (2020). Critical Discourse Analysis on "We are the World 25 for Haiti" Song Lyrics. Journal of English Education and Teaching (JEET), e-ISSN: 2622-5867, p-ISSN: 2685-743x, Volume 4 number 1, March 2020, Page 36-48. Retrieved from https://ejournal.unib.ac.id/index.php/JEET/article/view/9710

Hutajulu, F. L. S. and Herman. (2019). Analysis of Illocutionary Act in the Movie "You Are My Home" English Subtitle". Journal of English Educational Study Volume 2 Issue 1 May 2019 Page 29-36. E-ISSN: 2655-0776. Retrieved from http://jurnal.stkippersada.ac.id/jurnal/index.php/JEES/article/view/371

Kusumo, D. W. (2015). A Pragmatic Analysis of Illocutionary Acts in English Teaching Learning Process in SMA N 1 Wates Kulon Progo. Yogyakarta. Unpublished writing.

Leech, Geoffrey. 1983. Principles Of Pragmatics. Harmondsworth: Penguin.

Mappiasse, S. and Johari, A, (2014). Evaluation of English as a foreign language and its curriculum in Indonesia: A review. English language teaching. Faculty of education, $7(10), 113-122$

Moleong, Lexy J. 2011. Metodologi Penelitan Kualitatif. Bandung: PT Remaja Rosda Karya

Mono, U., et al. (2018). Pragmatic Presupposition in Waspada Daily Articles. Budapest International Research and Critics Institute-Journal (BIRCI-Journal). P. 7-12.

Mufiah, N. and Rahman, M. (2018). Speech Acts Analysis Of Donald Trump's Speech. Professional Journal of English Education. Vol. 1, No 2.

Pasaribu, B., Herman, and Hutahaean, D. T. (2020). Students' Difficulties In Translating Narrative Text From English Into Indonesia At Grade VIII Of SMP Negeri 9 Pematangsiantar. Acitya: Journal of Teaching \& Education, Vol. 2 No. 1 2020, PP. 12-18. Retrieved from http://journals.umkt.ac.id/index.php/acitya/article/view/1311

Prakasa, Bayu. 2017. The Analysis of Illocutionary Acts in the Titanic Movie. Jurnal Humanis, Fakultas Ilmu Budaya Unud Vol 21.1. English Department, Faculty of Arts, Udayana University, Indonesia.

Purba, R. and Herman. (2020). Multimodal Analysis on Ertiga Car Advertisement. Wiralodra English Journal (WEJ), Vol 4 No 1 Maret 2020, PP. 21-32. Retrieved from http://wej.unwir.ac.id/index.php/wej/article/view/77

Ridwan, M. (2018). National and Official Language: The Long Journey of Indonesian Language. Budapest International Research and Critics Institute-Journal (BIRCIJournal). P. 72-78.

Sinaga, Y. K., Herman, and Siahaan, P. L. (2020). The Effect of Partner Reading Strategy on Reading Comprehension. Journal of English Education and Teaching (JEET), eISSN: 2622-5867, p-ISSN: 2685-743x, Volume 4 number 2, June 2020, Page 206218. Retrieved from https://ejournal.unib.ac.id/index.php/JEET/article/view/10206

Sinaga, H., Herman., and Pasaribu, E. (2020). The Effect of Anagram Game on Students' Vocabulary Achievement at Grade Eight of SMP Negeri 8 Pematangsiantar. Journal of English Educational Study, Volume 3 Issue 1 May 2020, Page 51-60 E-ISSN: 2655-0776. Retrieved from http://jurnal.stkippersada.ac.id/jurnal/index.php/JEES/article/view/655

Sugiyono. 2007. Metode Penelitian Kuantitatif, Kualitatifdan R\&D. Alfabeta. 
Supriyadi, S. (2020). Pragmatic Analysis on G.M. Sudarta's Caricatures in Kompas Newspaper. Budapest International Research and Critics Institute-Journal (BIRCIJournal). P. 367-378.

Violeta, R. (2019). Speech Act Analysis of The Main Character in Maleficient Movie Scrip By Jane McTee. English Education TarbiyahAnd Teacher Training Faculty University of Islamic State RadenIntan Lampung.

Wadana, Muhammad. Roy, Sumita, Ariska Juan. 2019. Illocutionary Acts in President Rodrigo Duterte'sSpeech.International Journal of Cultural and Art Studies (IJCAS) Vol. 03, No. 1, 40 - 46. Faculty of Communication and Languages, University of Harapan Medan, Indonesia

Yule, G. 1996. Pragmatics. Oxford: Oxford University Press 